\title{
Human neuroblastoma SH-SY5Y cells treated with okadaic acid express phosphorylated high molecular weight tau- immunoreactive protein species
}

\author{
Mirta Boban ${ }^{1}$, Mirjana Babić Leko1, Terezija Miškić ${ }^{1}$, Patrick R. Hof ${ }^{2}$, and Goran Šimić1,* \\ ${ }^{1}$ Department of Neuroscience, Croatian Institute for Brain Research, University of Zagreb Medical \\ School, Zagreb, Croatia \\ ${ }^{2}$ Fishberg Department of Neuroscience, Ronald M. Loeb Center for Alzheimer's Disease, and \\ Friedman Brain Institute, Icahn School of Medicine at Mount Sinai, New York, NY, United States of \\ America
}

\begin{abstract}
Background: Early stages of Alzheimer's disease (AD) are characterized by high phosphorylation of microtubule-associated protein tau, which may result from the downregulation of protein phosphatases.
\end{abstract}

New method: In order to model phosphatase downregulation and analyze its effect on tau aggregation in vitro, we treated neuroblastoma SH-SY5Y cells with okadaic acid (OA), a protein phosphatase inhibitor, and examined high molecular weight phospho-tau species.

Results and comparison with existing methods: OA treatment led to the appearance of heat-stable protein species with apparent molecular weight around $100 \mathrm{kDa}$, which were immunoreactive to anti-tau antibodies against phosphorylated Ser202 and Ser396. As these high molecular weight tau-immunoreactive proteins (HMW-TIPs) corresponded to the predicted size of two tau monomers, we considered the possibility that they represent phosphorylation-induced tau oligomers. We attempted to dissociate HMW-TIPs by urea and guanidine, as well as by alkaline phosphatase treatment, but HMW-TIPs were stable under all conditions tested. These characteristics resemble properties of certain sodium dodecyl sulfate (SDS)-resistant tau oligomers from AD brains. The absence of HMW-TIPs detection by anti-total tau antibodies Tau46, CP27

*corresponding author gsimic@hiim.hr.

Author Contributions. Declaration of authorship. GŠ conceived and directed the project, coordinated experiments and co-wrote the paper. MB designed, performed and interpreted experiments and co-wrote the paper. MBL established the experimental model, performed and interpreted initial experiments and contributed with the data for the revision. TM performed and analyzed experiments under supervision of MB. PRH substantially contributed to the interpretation of data for the work. All authors contributed to revising and editing the manuscript critically for important intellectual content. All authors approved the final version of the manuscript.

Competing interests. All authors have completed the Unified Competing Interest form at www.icmje.org/coi_disclosure.pdf (available on request from the corresponding author) and declare no financial relationships with any organizations that might have an interest in the submitted work in the previous three years. All authors declare no other relationships or activities that could appear to have influenced the submitted work.

Publisher's Disclaimer: This is a PDF file of an unedited manuscript that has been accepted for publication. As a service to our customers we are providing this early version of the manuscript. The manuscript will undergo copyediting, typesetting, and review of the resulting proof before it is published in its final citable form. Please note that during the production process errors may be discovered which could affect the content, and all legal disclaimers that apply to the journal pertain. 
and Tau13 may be a consequence of epitope masking and protein truncation. Alternatively, HMWTIPs may represent previously unreported phosphoproteins cross-reacting with tau.

Conclusions: Taken together, our data provide a novel characterization of an OA-based cell culture model in which OA induces the appearance of HMW-TIPs. These findings have implications for further studies of tau under the conditions of protein phosphatase downregulation, aiming to explain mechanisms involved in early events leading to AD.

\section{Keywords}

Alzheimer's disease; neurodegeneration; cell culture; SH-SY5Y; okadaic acid; oligomerization; phosphorylation; protein phosphatase; tau protein; immunoblot

\section{Introduction}

One of the neuropathological hallmarks of Alzheimer's disease (AD) is the aggregation of tau protein in neurofibrillary tangles (NFT) in the neurons and glia cells in the brain. Tau (tubulin-associated unit) is a microtubule-associated protein, expressed mainly in neurons of the central nervous system [1], where its primary function is to modulate microtubule dynamics [2]. In adult human brain, there are six tau splicing isoforms ranging from 352 to 441 amino acids (for review, see [3]). Isoforms differ by the absence or presence of one or two 29 amino acid inserts in the N-terminal part in combination with either three or four microtubule-binding (MTB) repeat regions in the C-terminal part (for review, see [4]).

Tau is normally a natively unfolded protein [5] with little tendency for aggregation, therefore an intriguing, but mostly unresolved question is to understand what causes wild-type tau molecules to oligomerize and subsequently form larger aggregates that form NFT. Pathways leading to tau aggregation are largely unclear. However, tau propensity to aggregate may be driven by posttranslational modifications, mainly phosphorylation and C-terminal truncation [6]. Despite a paucity of stable secondary structure, tau in solution seems to form a transient global fold in which N- and C-terminal arms fold over the central MTB repeat domain that contains the sequences with a tendency to form $\beta$-sheets and aggregate (known as the "paper clip" model [7]).

Phosphorylation decreases affinity of tau for microtubules and makes it more prone to aggregation (for review, see [8]). In AD brains more than thirty tau amino acid residues are specifically phosphorylated, including Ser202 and Ser396 [9]. Hyperphosphorylation of tau in $\mathrm{AD}$ seems to be a consequence of a disrupted balance between kinase and phosphatase activity [10]. Several protein phosphatases were found dysregulated in AD brain, including PP2A, PP1 and PP5, which are all capable of dephosphorylating tau in vitro (for review, see [11]. The main regulator of tau dephosphorylation in healthy human brain appears to be PP2A, since its activity accounted for about $70 \%$ of the tau dephosphorylation in the assay using brain extracts [12]. PP2A has been shown to dephosphorylate tau in vitro at multiple sites, including Ser202 and Ser396 [13]. PP2A affects tau phosphorylation levels not only directly, but also indirectly by regulating the activities of several tau kinases, most notably glycogen synthase kinase $3 \beta$ (GSK-3 $\beta$ ) and $\mathrm{Ca}^{2+} /$ calmodulin-dependent protein kinase II (CaMKII) [14]. 
Studying the process of tau aggregation requires a suitable cell culture model. In this report we examined the potential of SH-SY5Y cell line treated with the phosphatase inhibitor okadaic acid (OA) as a model for studying the initial steps of tau aggregation. SH-SY5Y is a widely used human neuroblastoma cell line with an endogenous expression of tau and the capacity to differentiate into neuron-like cells [15-17]. Okadaic acid is a cell-permeable potent inhibitor of protein phosphatases PP2A, PP4, PP5 and PP1 [18, 19], which has been previously used to upregulate the levels of phospho-tau in cultured cells and to investigate the role of protein phosphatases in tau phosphorylation [20-24]. To investigate the potential of SH-SY5Y cells treated with protein phosphatase inhibitor OA as a model for studying the process of tau aggregation and neurodegeneration [25], we examined the effects of OA treatment on generation of high molecular weight tau. We observed that the incubation of SH-SY5Y cells with OA leads to the expression of a high molecular weight phospho-protein species immunoreactive to tau antibodies against phosphorylated Ser202 and phosphorylated Ser396.

\section{Materials and Methods}

\subsection{Cell culture}

Cells SH-SY5Y (ECACC, 94030304) were grown in Dulbecco's modified Eagle medium (DMEM, Gibco, Gaithersburg, MD, USA, cat. no. 31885-049) supplemented with $10 \%$ fetal bovine serum (FBS, Gibco, cat. no. 10270106), 1\% L-glutamine (Gibco, cat. no. 25030024), $1 \%$ non-essential amino acids (Sigma-Aldrich, Darmstadt, Germany, cat. no. M7145) and $1 \%$ penicillin-streptomycin (Gibco, cat. no. $15140-122$ ) at $37^{\circ} \mathrm{C}$ in humidified atmosphere with $5 \% \mathrm{CO}_{2}$. Unless indicated otherwise, undifferentiated SH-SY5Y cells grown to 60$90 \%$ confluency were used. For differentiation into neuron-like type, we followed the protocol described by Encinas and colleagues [26] with minor modifications. Briefly, cells were seeded at density of 10,000 cells $/ \mathrm{cm}^{2}$ in the medium described above. The following day a medium containing $10 \mu \mathrm{M}$ all-trans retinoic acid was added to the cells and incubated for five days, the medium being replaced every other day. Cells were washed with serumfree medium and incubated in medium containing $1 \% \mathrm{FBS}$ and $50 \mathrm{ng} / \mathrm{ml}$ brain-derived neurotrophic factor (BDNF, Sigma-Aldrich, cat. no. SRP3014) for two days. Cells were photographed using phase contrast microscopy (Zeiss, Oberkochen, Germany). Where indicated, cells were treated with indicated concentration of OA (Abcam, Cambridge, UK, cat. no. ab120375) added from $100 \mu \mathrm{M}$ OA solution in dimethyl sulfoxide (DMSO). As a negative control, an equal amount of DMSO to the one used in OA solution was applied to the cells.

\subsection{Testing cell viability by MTT assay}

Cell viability was tested using MTT assay. In short, cells were grown in 96-well plates containing $100 \mu \mathrm{l}$ cell culture medium and treated with $30 \mathrm{nM}$ OA, added from a $100 \mu \mathrm{M}$ OA solution in DMSO. For control, an equal amount of DMSO as used in OA solution was added to cells. After $8 \mathrm{~h}, 40 \mu \mathrm{l}$ of MTT (3-(4,5-dimethylthiazol-2-yl)-2,5diphenyltetrazolium bromide) was added to each well and samples were incubated at $37^{\circ} \mathrm{C}$ for $3 \mathrm{~h}$, followed by the addition of $160 \mu \mathrm{l}$ of DMSO. Absorbance at $570 \mathrm{nM}$ was measured using BioRad XR680 microplate reader (BioRad Laboratories, Hercules, CA, USA). 


\subsection{Preparation of cell lysates and protein extraction}

Upon harvesting, cells were washed in ice-cold Tris-buffered saline (TBS) buffer ( $20 \mathrm{mM}$ Tris- $\mathrm{HCl} \mathrm{pH} 7.4,150 \mathrm{mM} \mathrm{NaCl})$ and resuspended in Laemmli buffer $(50 \mathrm{mM}$ Tris- $\mathrm{HCl} \mathrm{pH}$ $6.8,2 \%$ sodium dodecyl sulfate [SDS], 2 mM ethylenediaminetetraacetic acid [EDTA], 10\% glycerol, 1 "Complete Mini" protease inhibitor cocktail tablet per $10 \mathrm{ml}$ [Roche Diagnostics, Basel, Switzerland cat. no. 11836170001, Roche Diagnostics, Basel, Switzerland], $1 \mathrm{mM}$ phenylmethylsulfonyl fluoride [added from a 100x concentrated solution in DMSO], $10 \mathrm{mM}$ sodium fluoride, $20 \mathrm{mM} \beta$-glycerophosphate, and $2 \mathrm{mM}$ sodium orthovanadate). For experiments shown in Figures 1E, 2B, and 3A cells were resuspended in 2x Laemmli buffer without prior washing step. $\beta$-mercaptoethanol $(2-5 \%)$ was present in the lysis buffer and samples were denatured at $90^{\circ} \mathrm{C}$ or $95^{\circ} \mathrm{C}$ for $5-15 \mathrm{~min}$. For the experiment shown in Figures $1 \mathrm{~A}, 1 \mathrm{~B}, 3 \mathrm{D}$, and $\mathrm{S} 1$ cells were resuspended in ice-cold radioimmunoprecipitation assay (RIPA) buffer (20 mM Tris- $\mathrm{HCl} \mathrm{pH} 7.4,1 \%$ Triton X-100, 0.1\% sodium dodecyl sulfate, $0.5 \%$ sodium-deoxycholate, $150 \mathrm{mM} \mathrm{NaCl}, 1 \mathrm{mM}$ EDTA, $10 \%$ glycerol, protease and phosphatase inhibitors as described above), drawn through $23 \mathrm{G}$ needle 8 times and incubated on ice for $30 \mathrm{~min}$. Samples were centrifuged at 20,000 $\mathrm{g}$ for $10 \mathrm{~min}$ at $4^{\circ} \mathrm{C}$, supernatant was collected, mixed with Laemmli buffer containing 5\% $\beta$-mercaptoethanol and incubated at $95^{\circ} \mathrm{C}$ for $5 \mathrm{~min}$. For the experiment in Fig. S1, prior to adding Laemmli buffer, samples were incubated at $85^{\circ} \mathrm{C}$ for $10 \mathrm{~min}$ and centrifuged at $20,000 \mathrm{~g}$ for $10 \mathrm{~min}$. For urea treatment, cells were resuspended in $2 \mathrm{x}$ Laemmli buffer containing $8 \mathrm{M}$ urea, samples were incubated at $65^{\circ} \mathrm{C}$ for $10 \mathrm{~min}$, centrifuged at $20,000 \mathrm{~g}$ for $20 \mathrm{~min}$ at room temperature (RT) and the supernatant was collected.

\subsection{Cell extraction by guanidine-hydrochloride}

Cells harvested by trypsinization were washed in ice-cold phosphate-buffered saline (PBS) and resuspended in a solution containing $6 \mathrm{M}$ guanidine-hydrochloride, $20 \mathrm{mM}$ Tris- $\mathrm{HCl} \mathrm{pH}$ 7.4 and $100 \mathrm{mM} \mathrm{NaCl}$, incubated at RT for $10 \mathrm{~min}$. Suspension was drawn through $23 \mathrm{G}$ needle and incubated at RT for $20 \mathrm{~min}$, followed by centrifugation at 20,000 $\mathrm{g}$ for $5 \mathrm{~min}$ at $4^{\circ} \mathrm{C}$ (Fig. S3B) or $20 \mathrm{~min}$ at RT (Fig. 5B). The supernatant was collected and the centrifugation step repeated. Guanidine hydrochloride forms a precipitate with SDS and is thus incompatible with SDS-PAGE [27]. To remove guanidine hydrochloride, proteins from the supernatant were precipitated by incubation in $90 \%$ ethanol at $-20^{\circ} \mathrm{C}$ for $1 \mathrm{~h}$. The samples were centrifuged at $20,000 \mathrm{~g}$ for 10 or $20 \mathrm{~min}$ at $4^{\circ} \mathrm{C}$, the pellet was washed in absolute ethanol and air-dried. For the experiment shown in Fig. 5B, precipitated proteins were solubilized in 2x Laemmli buffer (100 mM Tris-HCl pH 6.8, 4\% SDS, 4 mM EDTA, $10 \%$ glycerol, 1 Roche "Complete Mini" protease inhibitor cocktail tablet per $10 \mathrm{ml}, 1 \mathrm{mM}$ phenylmethylsulfonyl fluoride, $10 \mathrm{mM}$ sodium fluoride, $20 \mathrm{mM} \beta$-glycerophosphate and 2 $\mathrm{mM}$ sodium orthovanadate) containing $8 \mathrm{M}$ urea, incubated at $37^{\circ} \mathrm{C}$ for $20 \mathrm{~min}$, and centrifuged at 20,000 $\mathrm{g}$ for $20 \mathrm{~min}$ at RT. $\beta$-mercaptoethanol was added to supernatant to a final concentration of $5 \%$ and the centrifugation step repeated. For the experiment shown in Fig. S3B, precipitated proteins were solubilized in a volume of RIPA buffer, followed by the addition of a third of the volume of concentrated Laemmli buffer containing $5 \% \beta$ mercaptoethanol, incubation at $95^{\circ} \mathrm{C}$ for $5 \mathrm{~min}$, centrifugation at 20,000 $\mathrm{g}$ at RT and the collection of the supernatant. 


\subsection{Heat-stable protein fraction}

To prepare heat stable fraction, we followed the protocol described by Petry et al. with some modifications [28]. Briefly, the cells harvested by Versene (Gibco, cat. no. 15040-066) were resuspended in $300 \mu \mathrm{l}$ lysis buffer $(50 \mathrm{mM}$ Tris- $\mathrm{HCl} \mathrm{pH}$ 7.4, $1 \%$ Triton X-100, $0.25 \%$ sodium-deoxycholate, $150 \mathrm{mM} \mathrm{NaCl}, 1 \mathrm{mM}$ EDTA, 10\% glycerol, 1 Roche "Complete Mini" protease inhibitor cocktail tablet per $10 \mathrm{ml}, 1 \mathrm{mM}$ phenylmethylsulfonyl fluoride, 10 $\mathrm{mM}$ sodium fluoride, $20 \mathrm{mM} \beta$-glycerophosphate, and $2 \mathrm{mM}$ sodium orthovanadate), incubated on ice for $10 \mathrm{~min}$, drawn through $23 \mathrm{G}$ needle eight times, incubated on ice for 20 $\min$ and centrifuged at $20,000 \mathrm{~g}$ for $20 \mathrm{~min}$ at $4^{\circ} \mathrm{C}$. The supernatant was collected and incubated at $95^{\circ} \mathrm{C}$ for $10 \mathrm{~min}$, followed by centrifugation at $20,000 \mathrm{~g}$ for $10 \mathrm{~min}$ at $4^{\circ} \mathrm{C}$. Supernatant containing the heat-stable fraction (protein concentration of $0.4-0.5 \mu \mathrm{g} / \mu \mathrm{l}$ ) was separated from the pellet. A volume of the heat-stable fraction $(150-200 \mu \mathrm{l})$ was incubated with one third of the volume of concentrated Laemmli buffer ( $8 \%$ SDS, $200 \mathrm{mM}$ Tris- $\mathrm{HCl}$ pH 6.8, 8 mM EDTA, 20\% glycerol). The amount of the heat stable protein samples loaded on gel was $12 \mu \mathrm{g}$ of protein. The pellet was resuspended in a similar volume of radioimmunoprecipitation assay (RIPA) buffer and concentrated Laemmli buffer.

\subsection{Alkaline phosphatase treatment of protein lysates}

The cells were treated with $100 \mathrm{nM}$ OA for $2 \mathrm{~h}$, trypsinized, washed in PBS buffer and resuspended in lysis buffer $(50 \mathrm{mM}$ Tris- $\mathrm{HCl} \mathrm{pH} 7.9,1 \%$ Triton $\mathrm{X}-100,0.25 \%$ sodiumdeoxycholate, $150 \mathrm{mM} \mathrm{NaCl}, 1 \mathrm{mM} \mathrm{MgCl} 2,1$ Roche "Complete Mini" protease inhibitor cocktail tablet per $10 \mathrm{ml}, 1 \mathrm{mM}$ phenylmethylsulfonyl fluoride, $10 \mathrm{mM}$ sodium fluoride, 20 $\mathrm{mM} \beta$-glycerophosphate), incubated on ice for $10 \mathrm{~min}$, drawn through $23 \mathrm{G}$ needle eight times, incubated on ice for $20 \mathrm{~min}$ followed by $5 \mathrm{~min}$ centrifugation at $20,000 \mathrm{~g}$ at $4^{\circ} \mathrm{C}$ and the supernatant (protein concentration of $0.4 \mu \mathrm{g} / \mu \mathrm{l}$ ) was collected. To enrich heat stable proteins, the sample was incubated at $95^{\circ} \mathrm{C}$ for $10 \mathrm{~min}$, followed by centrifugation at 20,000 $\mathrm{g}$ for $20 \mathrm{~min}$ at $4^{\circ} \mathrm{C}$. The supernatant $(10 \mu \mathrm{l})$ was incubated with $10 \mathrm{U}$ of alkaline phosphatase (Promega, Fitchburg, WI, USA, cat. no. M2825) or water (control) at $37^{\circ} \mathrm{C}$ for $30 \mathrm{~min}$, followed by addition of Laemmli buffer and $5 \mathrm{~min}$ incubation at $95^{\circ} \mathrm{C}$. The whole reaction mixture was loaded on gel for analysis by immunoblot.

\subsection{Immunoblotting}

Proteins in cell extracts were separated on 7.5\% (Figures 1E, 3C, and 6) or 10\% (all other figures) SDS-PAGE gels and transferred onto a nitrocellulose membrane in the transfer buffer ( $25 \mathrm{mM}$ Tris, $192 \mathrm{mM}$ glycine), using the voltage of $50 \mathrm{~V}$ for the duration of $2 \mathrm{~h}$. The membrane was blocked in 5\% milk diluted in TBS or phosphate-buffered saline (PBS; 137 $\mathrm{mM} \mathrm{NaCl}, 2.7 \mathrm{mM} \mathrm{KCl}, 10 \mathrm{mM} \mathrm{Na}_{2} \mathrm{HPO}_{4}, 1.8 \mathrm{mM} \mathrm{KH}_{2} \mathrm{PO}_{4}$ ) and incubated with primary antibody diluted in TBS or PBS containing 5\% milk or 3\% bovine serum albumin, overnight at $4{ }^{\circ} \mathrm{C}$. The primary antibodies and their working dilutions used were: anti-tau-pS396 (Abcam, cat. no. ab109390, 1:10,000 dilution), Tau46 (Sigma-Aldrich, cat. no. T9450, dilution 1:1,000), anti-tau-pS202 (CP13, mouse monoclonal, gift of Prof. Peter Davies, dilution 1:500), anti-total tau mouse monoclonal antibody CP27 (gift of Prof. Peter Davies, dilution 1:250), Tau13 (Santa Cruz Biotechnology, Santa Cruz, CA, USA, cat. no. sc-21796, dilution 1:250), polyclonal anti-tau (DAKO-Agilent, CA, USA, cat. no. A-0024, dilution 
1:10000), anti-MAP2 (clone HM-2, Sigma-Aldrich, cat. no. M4403, dilution 1:1000), DC11 (generous gift from dr. Michal Novak, dilution 1:50), anti- $\beta$-actin (Sigma-Aldrich, cat. no. A5441, dilution 1:10,000), and anti-GAPDH (glyceraldehyde 3-phosphate dehydrogenase, Cell Signaling, Leiden, Netherlands, cat. no. 2118, dilution 1:1,000 to 1:2,000). The secondary antibodies were horse radish peroxidase-linked IgG (Cell Signaling, cat. no. 7074 and 7076). Proteins were visualized using Super Signal West substrate (Thermo Scientific, Waltham, MA, USA, Pico cat. no. 34077 or Femto cat. no. 34095) and imager ChemiDoc XRS+ with ImageLab software (BioRad Laboratories, Hercules, CA, USA). Exposure times were selected to maximize the signal to noise ratio. In the Fig. 1E, where the signal of samples present on two separate pieces of membrane is compared, membranes were imaged simultaneously. In Fig. 4, heat-stable fraction and pellet samples were present and analyzed on the same membrane and imaged simultaneously. Where appropriate, equal loading of samples on gel was assessed using GAPDH levels. Figures are showing representative images of data that were generated from at least three independent samples, or two independent experiments performed on different days, each containing two independent samples generated from separate cell culture dishes, treatment, harvesting and protein preparation. Where appropriate, data were analyzed using ImageLab software (BioRad Laboratories, Hercules, CA, USA).

\section{Results}

\subsection{OA treatment of SH-SY5Y cells induced expression of $100 \mathrm{kDa}$ proteins immunoreactive with anti-tau-pS202 and anti-tau-pS396 antibodies}

To inhibit the activity of protein phosphatases, we incubated undifferentiated neuroblastoma SH-SY5Y cells that endogenously express tau with OA. Taking into consideration the OA concentration necessary to inhibit the activity of different tau protein phosphatases and possible high local concentration of phosphatases in the cultures [18], we initially treated the cells with $100 \mathrm{nM} \mathrm{OA} \mathrm{(Fig.} \mathrm{1A} \mathrm{and} \mathrm{1B).} \mathrm{A} \mathrm{similar} \mathrm{concentration} \mathrm{had} \mathrm{been} \mathrm{used} \mathrm{in} \mathrm{previous}$ studies [29-31]. Proteins from total cell protein lysates were separated by denaturing SDS polyacrylamide gel electrophoresis (SDS-PAGE). Tau phosphorylation at specific epitopes was assessed by immunoblot using phospho-specific tau antibodies. Using the antibody that recognizes tau phosphorylated at S396, we observed protein bands of the apparent molecular weight of 50-65 kDa in samples from both treated (OA+) and untreated (OA-) cells (Fig. 1A). Additionally, a protein co-migrating with the molecular weight of $\sim 100 \mathrm{kDa}$ appeared in samples from cells treated with OA. The same samples were analyzed with the antibody CP13 that recognizes tau phosphorylated at S202 (Fig. 1B). In cells treated with OA a protein with an apparent molecular weight of $\sim 100 \mathrm{kDa}$ was clearly visible, while in samples from untreated cells the signal was very weak or not detectable, indicating that under normal growth conditions endogenous tau is phosphorylated at S202 at low levels. The $100 \mathrm{kDa}$ phospho-tau immunoreactive proteins were also induced upon cell treatment with lower OA concentrations of $30 \mathrm{nM}$ OA for $8 \mathrm{~h}$ (Fig. 1C) and with $20 \mathrm{nM}$ OA for $4 \mathrm{~h}$ (Fig. S1). Notably, MTT assay on cells treated with $30 \mathrm{nM}$ OA for $8 \mathrm{~h}$ revealed that the viability of OA-treated cells was similar to control cells (Fig. 1D), suggesting that the appearance of $100 \mathrm{kDa}$ protein is not due to OA-induced cell toxicity. Furthermore, a similar pattern of OA-induced $100 \mathrm{kDa}$ phospho-tau immunoreactive protein was observed in SH-SY5Y cells differentiated 
into neuron-like cells (Fig. 2). Together, the data indicated that protein phosphatase inhibition by $\mathrm{OA}$ induced the formation of $100 \mathrm{kDa}$ protein species immunoreactive to taupS202 and taupS396. Based on the molecular size of the reported protein and its immunoreactivity with anti-tau antibodies, this result is consistent with the possibility of tau oligomerization.

This high molecular weight tau-immunoreactive protein species (HMW-TIPs) detected with CP13 and anti-tau-S396 antibodies migrated in the SDS-PAGE with nearly identical electrophoretic mobility. To test whether both CP13 and anti-tau-pS396 recognized the same protein, we divided the lane containing protein lysate from OA-treated cells on the nitrocellulose membrane in half by cutting it vertically. We incubated one half with antibody CP13 and the other half with antibody against tau-pS396 and aligned the halves for imaging (Fig. 1E). We noticed that the protein band recognized by the CP13 antibody migrated slightly slower than the anti-tau-pS396 antibody-reactive band (Fig. 1E), indicating two distinct protein species. These distinct protein bands could represent an identical tau splicing isoform containing different phosphorylation patterns or an additional posttranslational modification, such as protein truncation.

Next, we examined HMW-TIPs using anti-total tau antibodies that recognize tau regardless of its phosphorylation state. We analyzed OA-treated and -untreated samples using antibody Tau46 that recognizes an epitope in the C-terminal part of tau (aa 404-441). We observed that antibody Tau46 does not detect the $100 \mathrm{kDa}$ protein, although it recognizes $50 \mathrm{kDa}$ tau and a protein around $70 \mathrm{kDa}$ (Fig. 3A and Fig. 2B), which presumably represents a low molecular weight MAP2 isoform [32]. To test whether the $70 \mathrm{kDa}$ protein recognized by antibody Tau46 is a MAP2 isoform, we analyzed OA-treated samples with an anti-MAP2 antibody that detects all MAP2 isoforms (Fig. S2). In agreement with a previous report showing that SHSY5Y cells primarily express a $70 \mathrm{kDa}$ MAP2 isoform [33], the anti-MAP2 antibody recognized a protein of this size, similarly to Tau46. The $70 \mathrm{kDa}$ band was clearly distinct from the $100 \mathrm{kDa}$ protein visualized with antibody CP13 (Fig. S2, left panel).

Next, we used anti-total tau antibodies raised against other tau regions, Tau13 (epitope most likely within the first 35 aa), CP27 (whose epitope includes residues 130-150), and a rabbit polyclonal antibody raised against the C-terminal part of tau (aa 243-441). Despite the recognition of monomeric tau proteins, Tau13, CP27 and this polyclonal antibody did not detect HMW-TIPs (Fig. 3B-D). We further tested the reactivity of HMW-TIPs with antibody DC11 that has been reported to recognize truncated tau (aa 151-421) [34]. However, the pattern of DC11 antibody did not overlap with that of HMW-TIPs (Fig. 3E).

Taken together, we were unable to detect HMW-TIPs using several anti-total tau antibodies, which together cover tau epitopes in the $\mathrm{N}$-terminal, central and $\mathrm{C}$-terminal regions of tau, and additionally an antibody against a truncated version of tau. The lack of HMW-TIPs detection using these antibodies could be due to antigen masking within the oligomer or a combination of epitope masking and a different tau protein truncation. 


\subsection{HMW-TIPs are found in a heat-stable fraction}

To investigate the properties of HMW-TIPs, we examined whether it could be found in a heat-stable fraction. Due to their internally disordered structure, tau and other MAP2 family proteins are resistant to heat-induced precipitation. After isolating a heat-stable fraction using the protocol described by Petry and collaborators [28], in which cells are lysed in a buffer containing $1 \%$ non-ionic detergent Triton X-100, 0.25\% ionic detergent sodiumdeoxycholate and $150 \mathrm{mM} \mathrm{NaCl}$, but no SDS, the cell lysate was boiled and insoluble proteins were precipitated by centrifugation at $20,000 \mathrm{~g}$. As expected, antibody Tau 46 detected $50 \mathrm{kDa}$ tau and a $70 \mathrm{kDa}$ protein, presumably a MAP2 isoform [32] in the heatstable fraction, and no signal was observed in the pellet fraction (Fig. 4A, upper panels). In contrast, the levels of $\beta$-actin were much lower in the heat-stable fraction than in the pellet (Fig. 4A, lower panels). Together, this indicated that the heat-stable fraction was enriched in heat-stable proteins. Using the antibodies anti-tau-pS396 and CP13, we found that HMWTIPs were present in the heat-stable fraction (Fig. 4B). In conclusion, HMW-TIPs cofractionated with heat-stable Tau46-reactive proteins, which is a characteristic of proteins with internally disordered structure, including tau.

\subsection{HMW-TIPs are stable under reducing and strong denaturing conditions}

Considering the possibility that HMW-TIPs represent tau oligomers, we tested conditions under which oligomers could be dissociated. Previous reports have shown that tau oligomers can be disrupted under reducing conditions [35,36], although tau crosslinking by disulfide bonds is not an absolute prerequisite for tau aggregation. Cell lysates in all the experiments were prepared under reducing conditions, therefore this indicated that the stability of the putative oligomer does not depend on disulfide bonds. Next, we examined whether putative oligomers could be dissociated by strong denaturing agent urea and guanidine hydrochloride. Immunoblot analysis of cell lysates using CP13 antibody revealed that HMW-TIPs did not dissociate in the presence of either $8 \mathrm{M}$ urea (Fig. 5A) or $6 \mathrm{M}$ guanidine hydrochloride (Fig. 5B), and a similar result was obtained using anti-tau-pS396 antibody (Fig. S3). Quantification of HMW-TIPs signal relative to GAPDH levels in samples prepared with and without $8 \mathrm{M}$ urea revealed that there was no significant difference between anti-tau-pS396-reactive HMW-TIPs levels in samples from OA-treated cells extracted with and without urea (Fig. S3A), while the levels of CP13-immunoreactive HMW-TIPs were higher in cell lysates prepared with urea than without urea, presumably due to a better extraction in the presence of urea (Fig. 5A).

\subsection{Characterization of the HMW-TIPs species upon protein dephosphorylation}

Finally, to examine the impact of protein phosphorylation on the putative $100 \mathrm{kDa}$ tau oligomer, lysates of cells treated with OA were incubated with alkaline phosphatase. Because none of the tested anti-total tau antibodies recognized HMW-TIPs, this presented an obstacle in examining proteins upon dephosphorylation. Surprisingly, we observed that alkaline phosphatase treatment did not abolish detection of 55-60 kDa tau and HMW-TIPs by anti-tau-pS396 antibody (Fig. 6), although their electrophoretic mobility was slightly modified (Fig. 6, compare molecular weight of proteins in the samples treated and not treated with alkaline phosphatase). The change in electrophoretic mobility indicates that 
some amino acid residues were dephosphorylated, but not the S396 epitope. Under similar conditions of alkaline phosphatase treatment, CP13-dependent signal of HMW-TIPs was diminished (Fig. S4), indicating efficient dephosphorylation at the tau-S202 epitope. The fact that alkaline phosphatase treatment affects the migration rate of HMW-TIPs only to a small degree suggested that the putative oligomer does not dissociate into monomers upon partial protein dephosphorylation.

\section{Discussion}

We used SH-SY5Y cell culture model of protein phosphatase downregulation based on cell treatment with OA and showed that OA leads to the appearance of $100 \mathrm{kDa}$ protein species immunoreactive to phospho-tau specific antibodies CP13 (anti-tau-pS202) and anti-taupS396.

Based on its molecular size, we initially considered the possibility that HMW-TIPs represent large tau splicing isoform containing exon 4A (so-called "big tau"), which contains an additional 254 aa insert in the N-terminal part [37] and is normally expressed predominantly in the peripheral nervous tissue [38]. This would be in accordance with a previous report showing that SH-SY5Y cells and their parental line SK-N-SH express a tau isoform around $100 \mathrm{kDa}$ [16]. However, we were unable to detect HMW-TIPs using any of the antibodies used against total tau, namely Tau46, CP27, Tau13, and a rabbit polyclonal antibody. As "big tau" normally contains all of the epitopes recognized by these antibodies, with the possible exception of CP27, and these epitopes are not recognized by the anti-total tau antibodies we used, it is highly unlikely that HMW-TIPs represent "big tau".

Based on the observation that the molecular weight of the HMW-TIPs corresponds to the predicted size of two molecules of fetal tau, which is one of the most prominent tau isoforms in undifferentiated SH-SY5Y cells [17], we considered the possibility that it represents tau oligomers. In support of this possibility, a study using bimolecular fluorescence complementation showed that HEK293 cells expressing tau constructs fused to split Venus increase in fluorescence upon treatment of cells with $30 \mathrm{nM}$ OA for $24 \mathrm{~h}$, suggesting tau oligomerization [39]. The absence of oligomer detection by anti-total tau antibodies in our experiments could be a consequence of by epitope masking or a combination of epitope masking and protein truncation, which would render HMW-TIPs unrecognizable.

In attempt to dissociate putative oligomers by reducing and denaturing agents, we found that HMW-TIPs were stable in the presence of $\beta$-mercaptoethanol, SDS, urea and guanidine. The role of disulfide bridges in tau oligomerization is not entirely clear, as both reductionsensitive and reduction-resistant tau dimers have been previously observed [35, 36]. In our experiments, HMW-TIPs were detected in the presence of $\beta$-mercaptoethanol, indicating that the stability of a putative oligomer does not depend on disulfide bonds. Despite the fact that most protein complexes dissociate in the presence of SDS, some protein complexes remain assembled [40]. For example, SDS-resistant tau oligomers have been reported in AD brain [35]. Moreover, it has been previously reported that a pool of tau isolated from AD brain remained aggregated in high molecular mass structures even after the treatment with 8 $\mathrm{M}$ urea [41], whereas certain types of tau aggregates were stable in $6 \mathrm{M}$ guanidine 
hydrochloride [42]. Taken together, we were unable to dissociate putative oligomers with SDS, urea, and guanidine. However, the observed stability of HMW-TIPs in the presence of these agents is compatible with the characteristics of some previously reported tau oligomers.

The present study showed that treatment of cell lysates with alkaline phosphatase resulted in partially dephosphorylated HMW-TIPs, leaving the S396 epitope phosphorylated and the putative oligomer assembled. In fact, an inefficient removal of phosphates by alkaline phosphatase from the tau PHF-1 epitope, which includes pS396 and pS404, has been already reported [43]. Our data suggest that exhaustive tau phosphorylation is either not essential for the stability of the putative oligomer, or is necessary for initial oligomer formation, but once formed, oligomers could be stable even upon dephosphorylation. Based on our present data it is also possible that, in addition to other sites, dephosphorylation of S396 is required for the disassembly of the putative oligomer.

Finally, OA affects several cellular processes [45] and inhibition of protein phosphatases PP1, PP2A, PP4 and PP5 by OA is lethal to most human cells [18]. To minimize the toxic effect of OA on cells, we used treatment with OA concentrations of 100-150 nM for a short period of 2-2.5 h. Moreover, we have also observed the induction of the $100 \mathrm{kDa}$ anti-tau reactive protein using a lower OA concentration of $20 \mathrm{nM}$ for $4 \mathrm{~h}$ and upon cell treatment with $30 \mathrm{nM}$ OA for $8 \mathrm{~h}$, which did not affect cell viability, suggesting that the appearance of the $100 \mathrm{kDa}$ protein is not due to OA-induced cell toxicity. However, we cannot entirely exclude the possibility that OA-induced HMW-TIPs is not a direct consequence of tauimmunoreactive protein phosphorylation, but could arise due to an indirect effect of phosphatase inhibition by OA [44], or through a phosphatase-independent pathway [45].

In summary, OA treatment of SH-SY5Y cells lead to the appearance of HMW proteins immunoreactive to anti-tau-pS202 and -pS396 antibodies, which is in line with the possibility that HMW-TIPs represent tau oligomers. However, due to the inability to detect HMW-TIPs with anti-total tau antibodies and to dissociate putative oligomers under conditions tested, we cannot exclude the possibility that HMW-TIPs represent tau-unrelated proteins that are detected with anti-tau-pS202 and -pS396 antibodies due to cross-reactivity. The finding that anti-tau-pS396- and -pS202-immunoreactive HMW-TIPs exhibited almost identical, yet distinct electrophoretic mobilities in SDS-PAGE supports this possibility. Furthermore, although HMW-TIPs were present in the heat-stable fraction, which is a characteristic of tau and other intrinsically disordered proteins [46], it should be noted that due to the presence of $1 \%$ Triton X-100 and $0.25 \%$ sodium-deoxycholate in the lysis buffer, our protocol may have extracted a broader range of proteins than buffers without detergents.

In conclusion, we provide strong evidence that OA treatment of neuroblastoma cells in culture induces a high molecular weight phospho-tau immunoreactive species. Although additional research is required to clarify further the identity of the reported proteins, our findings indicate that OA-treated SH-SY5Y cells represent a potentially valuable cell culture model for studying tau oligomerization under the conditions of protein phosphatase downregulation, as well as tau aggregation inhibitors and neuroprotective compounds [4749]. Our findings may thus facilitate future studies aiming to explain molecular mechanisms 
involved in the early events leading to tau aggregation and neurodegeneration, which may eventually lead to effective therapy and prevention of neurofibrillary degeneration and AD.

\section{Supplementary Material}

Refer to Web version on PubMed Central for supplementary material.

\section{Acknowledgments.}

We would like to thank Dr. Peter Davies (Albert Einstein College of Medicine, Bronx, NY, USA) for the gift of antibodies CP13 and CP27 and Prof. Michal Novak (Institute of Neuroimmunology, Slovak Academy of Sciences, Bratislava, Slovak Republic) for the gift of DC11 antibody. We thank undergraduate student Ivan Ciganek for the technical assistance with the experiments for the revision of the manuscript.

Funding. This work was funded by the Croatian Science Foundation, grant no. IP-2014-09-9730, for the project "Tau protein hyperphosphorylation, aggregation, and trans-synaptic transfer in Alzheimer's disease: cerebrospinal fluid analysis and assessment of potential neuroprotective compounds" to GŠ, by the European Union through the European Regional Development Fund, Operational Programme Competitiveness and Cohesion, grant agreement no. KK.01.1.1.01.0007, CoRE - Neuro, and in part by NIH grant P50 AG005138 to PRH.

\section{Abbreviations}
AD
Alzheimer's disease
BDNF
brain-derived neurotrophic factor
CP13
antibody against phosphorylated tau Ser-202
CP27
antibody against total tau (aa 130-150)
DMEM
Dulbecco's modified Eagle medium
DMSO
dimethyl sulfoxide
EDTA
ethylenediaminetetraacetic acid
FBS
fetal bovine serum
GAPDH
glyceraldehyde 3-phosphate dehydrogenase
GSK-3 $\beta$
glycogen synthase kinase $3 \beta$
HMW-TIPs
high molecular weight tau-immunoreactive proteins
HS
heat-stable (fraction)
MAP
microtubule-associated protein
MTB
microtubule binding (repeat regions)
NFT neurofibrillary tangles
OA okadaic acid
PBS phosphate-buffered saline
PP2A protein phosphatase 2A 
RIPA radioimmunoprecipitation assay buffer

SDS-PAGE sodium dodecyl sulfate - polyacrylamide gel electrophoresis

Tau13 antibody against the N-terminal part of tau (aa 2-18)

Tau46 antibody against the C-terminal part of tau (aa 404-441)

TBS Tris-buffered saline

\section{References}

1. Binder LI; Frankfurter A; Rebhun LI The distribution of tau in the mammaliancentral nervous system. J. Cell Biol 1985, 101, 1371-1378. [PubMed: 3930508]

2. Qiang L; Sun X; Austin TO; Muralidharan H; Jean DC; Liu M; Yu W; Baas PW Tau does not stabilize axonal microtubules but rather enables them to have long labile domains. Curr. Biol 2018, 28, 2181-2189. [PubMed: 30008334]

3. Buée L; Bussière T; Buée-Scherrer V; Delacourte A; Hof PR Tau proteinisoforms, phosphorylation and role in neurodegenerative disorders. Brain Res. Rev 2000, 33, 95-130. [PubMed: 10967355]

4. Šimić G; Babić Leko M; Wray S; Harrington C; Delalle I; Jovanov-Milošević N; Bažadona D; de Silva R; Di Giovanni G; Wischik C; Hof PR Tau protein hyperphosphorylation and aggregation in Alzheimer's disease and other tauopathies, and possible neuroprotective strategies. Biomolecules 2016, E6. [PubMed: 26751493]

5. Uversky VN Natively unfolded proteins: a point where biology waits for physics.Protein Sci. 2002, 11, 739-756. [PubMed: 11910019]

6. Zhou Y; Shi J; Chu D; Hu W; Guan Z; Gong CX; Iqbal K; Liu F Relevanceof phosphorylation and truncation of tau to the etiopathogenesis of Alzheimer's disease. Front. Aging Neurosci 2018, 10, 27. [PubMed: 29472853]

7. Jeganathan S; von Bergen M; Brutlach H; Steinhoff HJ; Mandelkow E; Globalhairpin folding of tau in solution. Biochemistry 2006, 45, 2283-2293. [PubMed: 16475817]

8. Wang Y; Mandelkow E Tau in physiology and pathology. Nat. Rev. Neurosci2016, 17, 22-35. [PubMed: 26656254]

9. Duka V; Lee JH; Credle J; Wills J; Oaks A; Smolinsky C; Shah K; Mash DC; Masliah E; Sidhu A Identification of the sites of tau hyperphosphorylation and activation of tau kinases in synucleinopathies and Alzheimer's diseases. PLoS One 2013, 8, e75025. [PubMed: 24073234]

10. Šimić G; Gnjidić M; Kostović I Cytoskeletal changes as an alternative view on pathogenesis of Alzheimer's disease. Period. Biol 1998, 100, 165-173.

11. Martin L; Latypova X; Wilson CM; Magnaudeix A; Perrin ML; Terro F Tauprotein phosphatases in Alzheimer's disease: the leading role of PP2A. Ageing Res. Rev 2013, 12, 39-49. [PubMed: 22771380]

12. Liu F; Grundke-Iqbal I; Iqbal K; Gong CX Contributions of protein phosphatasesPP1, PP2A, PP2B and PP5 to the regulation of tau phosphorylation. Eur. J. Neurosci 2005, 22, 1942-1950. [PubMed: $16262633]$

13. Bennecib M; Gong CX; Grundke-Iqbal I; Iqbal K Role of protein phosphatase-2A and -1 in the regulation of GSK-3, cdk5 and cdc2 and the phosphorylation of tau in rat forebrain. FEBS Lett. 2000, 485, 87-93. [PubMed: 11086171]

14. Arif M; Wei J; Zhang Q; Liu F; Basurto-Islas G; Grundke-Iqbal I; Iqbal KCytoplasmic retention of protein phosphatase $2 \mathrm{~A}$ inhibitor 2 (I2PP2A) induces Alzheimer-like abnormal hyperphosphorylation of Tau. J. Biol. Chem 2014, 289, 27677-27691. [PubMed: 25128526]

15. Smith CJ; Anderton BH; Davis DR; Gallo JM Tau isoform expression andphosphorylation state during differentiation of cultured neuronal cells. FEBS Lett. 1995, 375, 243-248. [PubMed: 7498509]

16. Uberti D; Rizzini C; Spano PF; Memo M Characterization of tau proteins inhuman neuroblastoma SH-SY5Y cell line. Neurosci. Lett 1997, 235, 149-153. [PubMed: 9406891] 
17. Agholme L; Lindström T; Kågedal K; Marcusson J; Hallbeck M An in vitromodel for neuroscience: differentiation of SH-SY5Y cells into cells with morphological and biochemical characteristics of mature neurons. J. Alzheimers Dis 2010, 20, 1069-1082. [PubMed: 20413890]

18. Swingle M; Ni L; Honkanen RE Small-molecule inhibitors of Ser/Thr proteinphosphatases: specificity, use and common forms of abuse. Methods Mol. Biol 2007, 365, 23-38. [PubMed: 17200551]

19. Kamat PK; Rai S; Swarnkar S; Shukla R; Nath C Molecular and cellular mechanism of okadaic acid (OKA)-induced neurotoxicity: a novel tool for Alzheimer's disease therapeutic application. Mol. Neurobiol 2014, 50, 852-865. [PubMed: 24710687]

20. Tanaka T; Zhong J; Iqbal K; Trenkner E; Grundke-Iqbal I The regulation of tau in SY5Y neuroblastoma cells: the role of protein phosphatases. FEBS Lett. 1998, 426, 248-254. [PubMed: 9599018]

21. Medina M; Avila J; Villaneuva N Use of okadaic acid to identify relevantphosphoepitopes in pathology: a focus on neurodegeneration. Mar. Drugs 2013, 11, 1656-1668. [PubMed: 23697949]

22. Arendt T; Holzer M; Brückner MK; Janke C; Gärtner U The use of okadaicacid in vivo and the induction of molecular changes typical for Alzheimer's disease. Neuroscience 1998, 85, 1337 1340. [PubMed: 9681968]

23. Mudher AK; Perry VH Using okadaic acid as a tool for the in vivo induction ofhyperphosphorylated tau. Neuroscience 1998, 85, 1329-1332. [PubMed: 9681966]

24. Metin-Armağan D; Gezen-Ak D; Dursun E; Atasoy İL; Karabay A; Yılmazer S; Öztürk M Okadaic acid-induce tau hyperphosphorylation and the downregulation of Pin1 expression in primary cortical neurons. J. Chem. Neuroanat 2018, 92, 41-47. [PubMed: 29860071]

25. More SV; Kumar H; Cho DY; Yun YS; Choi DK Toxin-inducedexperimental models of learning and memory impairment. Int. J. Mol. Sci 2016, 17, E1447. [PubMed: 27598124]

26. Encinas M; Iglesias M; Liu Y; Wang H; Muhaisen A; Ceña V; Gallego C;Comella JX Sequential treatment of SH-SY5Y cells with retinoic acid and brain-derived neurotrophic factor gives rise to fully differentiated, neurotrophic factor-dependent, human neuron-like cells. J. Neurochem 2000, 75, 991-1003. [PubMed: 10936180]

27. Pepinsky RB Selective precipitation of proteins from guanidine hydrochloride-containing solutions with ethanol. Anal. Biochem 1991, 195, 177-181. [PubMed: 1888015]

28. Petry FR; Pelletier J; Bretteville A; Morin F; Calon F; Hébert SS;Whittington RA; Planel E Specificity of anti-tau antibodies when analyzing mice models of Alzheimer's disease: problems and solutions. PLoS One 2014, 9, e94251. [PubMed: 24788298]

29. Planel E; Yasutake K; Fujita SC; Ishiguro K Inhibition of protein phosphatase2A overrides tau protein kinase I/glycogen synthase kinase 3 beta and cyclin-dependent kinase 5 inhibition and results in tau hyperphosphorylation in the hippocampus of starved mouse. J. Biol. Chem 2001, 276, 34298-34306. [PubMed: 11441005]

30. Rahman A; Ting K; Cullen KM; Braidy N; Brew BJ; Guillemin GJ Theexcitotoxin quinolinic acid induces tau phosphorylation in human neurons. PLoS One 2009, 4, e6344. [PubMed: 19623258]

31. Zhang Z; Simpkins JW Okadaic acid induces tau phosphorylation in SH-SY5Ycells in an estrogenpreventable manner. Brain Res. 2010, 1345, 176-181. [PubMed: 20457142]

32. Kosik KS; Orecchio LD; Binder L; Trojanowski JQ; Lee VM; Lee GEpitopes that span the tau molecule are shared with paired helical filaments. Neuron, 1988, 1, 817-825. [PubMed: 2483104]

33. Constantinescu R; Constantinescu AT; Reichmann H; Janetzky B Neuronaldifferentiation and longterm culture of the human neuroblastoma line SH-SY5Y. J. Neural Transm. Suppl 2007, 72, $17-$ 28.

34. Vechterova L; Kontsekova E; Zilka N; Ferencik M; Ravid R; Novak M DC11:a novel monoclonal antibody revealing Alzheimer's disease-specific tau epitope. Neuroreport 2003, 14, 87-91. [PubMed: 12544837]

35. Sahara N; Maeda S; Murayama M; Suzuki T; Dohmae N; Yen SH;Takashima A Assembly of two distinct dimers and higher-order oligomers from full-length tau. Eur. J. Neurosci 2007, 25, 30203029. [PubMed: 17561815]

36. Sahara N; DeTure M; Ren Y; Ebrahim AS; Kang D; Knight J; Volbracht C;Pedersen JT; Dickson DW; Yen SH; Lewis J Characteristics of TBS-extractable hyperphosphorylated tau species: 
aggregation intermediates in rTg4510 mouse brain. J. Alzheimers Dis 2013, 33, 249-263. [PubMed: 22941973]

37. Goedert M; Spillantini MG; Crowther RA Cloning of a big tau microtubule-associated protein characteristic of the peripheral nervous system. Proc. Natl. Acad. Sci. USA 1992, 89, 1983-1987. [PubMed: 1542696]

38. Boyne LJ; Tessler A; Murray M; Fischer I Distribution of Big tau in the centralnervous system of the adult and developing rat. J. Comp. Neurol 1995, 358, 279-293. [PubMed: 7560287]

39. Tak H; Haque MM; Kim MJ; Lee JH; Baik JH; Kim Y; Kim DJ; Grailhe R; Kim YK Bimolecular fluorescence complementation; lighting-up tau-tau interaction in living cells. PLoS One 2013, 8, e81682. [PubMed: 24312574]

40. Bitan G; Fradinger EA; Spring SM; Teplow DB Neurotoxic protein oligomers - what you see is not always what you get. Amyloid 2005, 12, 88-95. [PubMed: 16011984]

41. Köpke E; Tung YC; Shaikh S; Alonso AC; Iqbal K; Grundke-Iqbal IMicrotubule-associated protein tau. Abnormal phosphorylation of a non-paired helical filament pool in Alzheimer disease. J. Biol. Chem 1993, 268, 24374-24384. [PubMed: 8226987]

42. Falcon B; Cavallini A; Angers R; Glover S; Murray TK; Barnham L; Jackson S; O’Neill MJ; Isaacs AM; Hutton ML; Szekeres PG; Goedert M; Bose S Conformation determines the seeding potencies and recombinant Tau aggregates. J. Biol. Chem 2015, 290, 1049-1065. [PubMed: 25406315]

43. Tepper K; Biernat J; Kumar S; Wegmann S; Timm T; Hübschmann S;Redecke L; Mandelkow EM; Müller DJ; Mandelkow E Oligomer formation of tau protein hyperphosphorylated in cells. J. Biol. Chem 2014, 289, 34389-34407. [PubMed: 25339173]

44. Van Dam AM; Bol JG; Binnekade R; van Muiswinkel FL Acute or chronicadministration of okadaic acid to rats induces brain damage rather than Alzheimer-like neuropathology. Neuroscience 1998, 85, 1333-1335. [PubMed: 9681967]

45. Valdiglesias V; Prego-Faraldo MV; Pásaro E; Méndez J; Laffon B Okadaicacid: more than a diarrheic toxin. Mar. Drugs 2013, 11, 4328-4349. [PubMed: 24184795]

46. Battisti A; Ciasca G; Grottesi A; Tenenbaum A Thermal compaction of theintrinsically disordered protein tau: entropic, structural, and hydrophobic factors. Phys. Chem. Chem. Phys 2017, 19, 8435-8446. [PubMed: 28287224]

47. Koss DJ; Robinson L; Mietelska-Porowska A; Gasiorowska A; Sepčić K; Turk T; Jaspars M; Niewiadomska G; Scott RH; Platt B; Riedel G Polymeric alkylpyridinium salts permit intracellular delivery of human Tau in rat hippocampal neurons: requirement of Tau phosphorylation for functional deficits. Cell. Mol. Life Sci 2015, 72, 4613-4632. [PubMed: 26070304]

48. Li R; Xu DE; Ma T Lovastatin suppresses the aberrant tau phosphorylation fromFTDP-17 mutation and okadaic acid-induction in rat primary neurons. Neuroscience 2015, 294, 14-20. [PubMed: 25770969]

49. Koehler D; Shah ZA; Hensley K; Williams FE Lanthionine ketamine-5-ethylester provides neuroprotection in a zebrafish model of okadaic acid-induced Alzheimer's disease. Neurochem. Int 2018, 115, 61-68. [PubMed: 29475037] 


\section{Highlights}

- $\quad$ OA treatment of SH-SY5Y cells induced $100 \mathrm{kDa}$ tau-immunoreactive species

- Induced HMW species were reactive to anti-tau-pS202 and anti-tau-p396 antibodies

- HMW species were heat-stable and stable in SDS, urea and guanidine

- $\quad$ OA-induced HMW species could not be detected by several anti-total tau antibodies

- HMW proteins may represent tau oligomers or phosphoproteins crossreacting with tau 
A

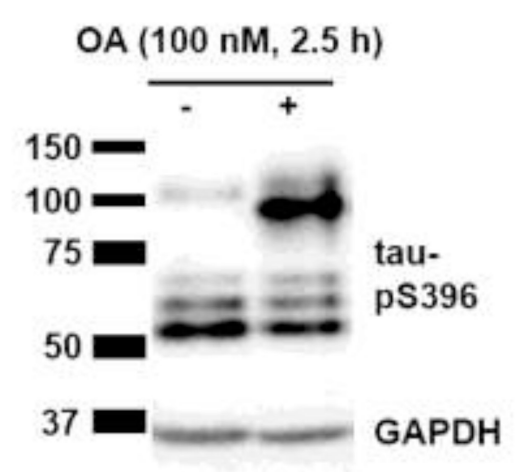

D

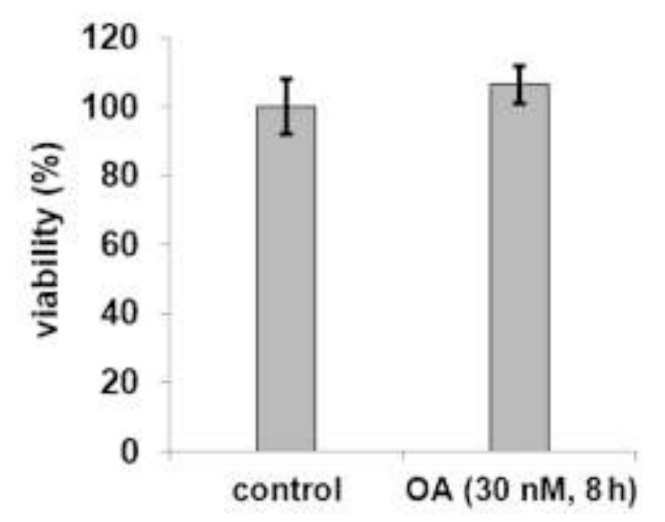

B

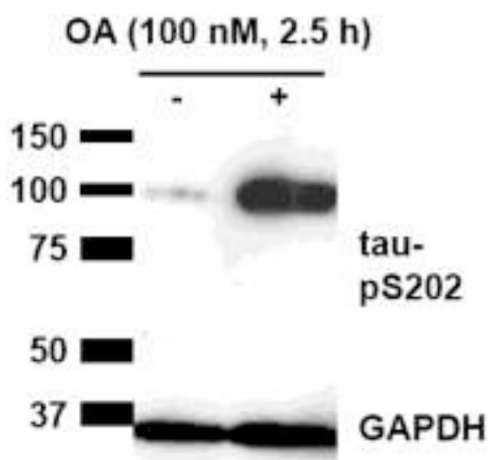

C

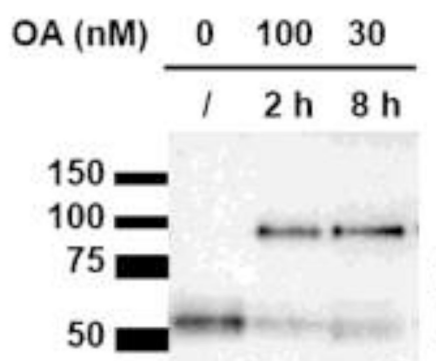

taupS396

GAPDH
E<smiles>[18OH]</smiles>

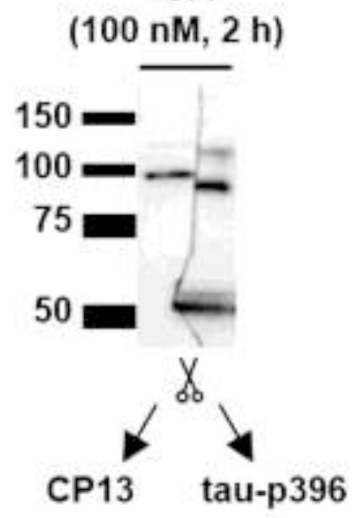

Figure 1. OA treatment of SH-SY5Y cells induces expression of a high molecular weight protein species immunoreactive to phospho-tau.

Undifferentiated SH-SY5Y cells were treated with indicated concentrations of OA for an indicated time period. Around $25 \mu \mathrm{g}$ protein in total cells lysates were analyzed by immunoblotting using antibodies that detect tau-pS396 or tau-pS202 (CP13). GAPDH served as a loading control (A-C). Note a strong band migrating around 100-kDa in lysates of OA-treated cells (A-C). (D) Viability of cells treated with $30 \mathrm{nM}$ OA for $8 \mathrm{~h}$ (number of independent samples $n=8)$ and control cells $(n=4)$ was tested using MTT assay. Percent viability of control cells is shown. No significant difference in viability was found $(\mathrm{t}=$ 0.372 , df $=10, p=0.125$ ). (E) Nitrocellulose membrane with transferred proteins was cut vertically in the middle of the lane (scissors) and the halves were incubated with CP13 or anti-tau-pS396 antibodies. Membranes were placed side-by-side and imaged simultaneously. 
A

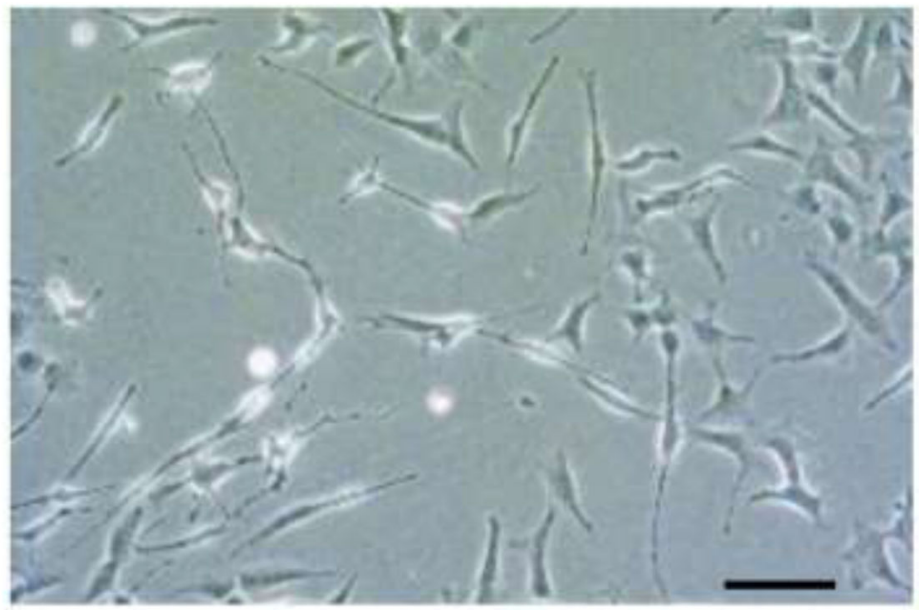

B

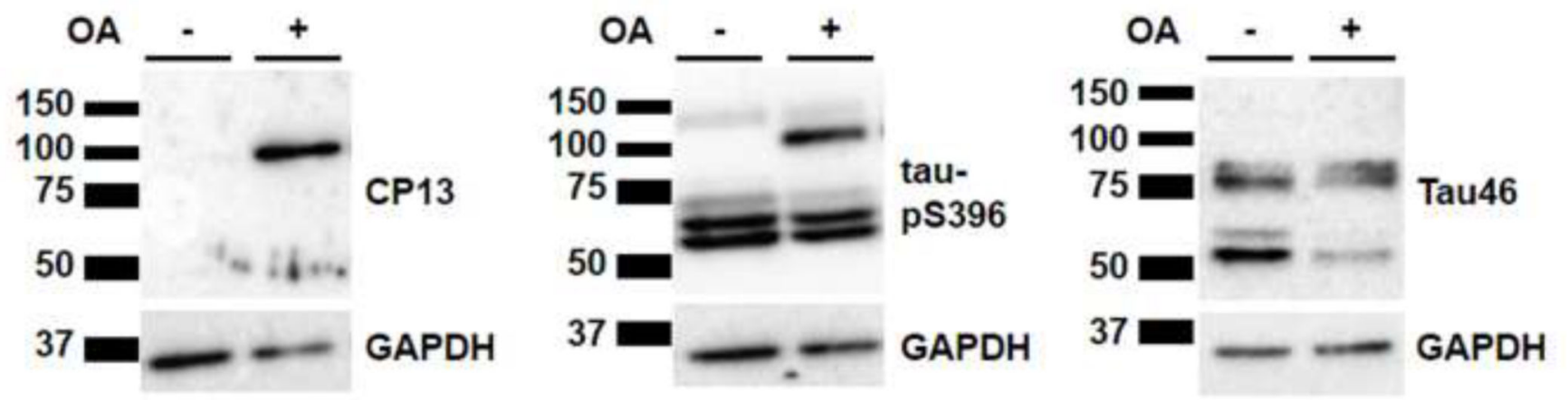

Figure 2. HMW-TIP is detected in OA-treated SH-SY5Y cells differentiated into neuron-like cells.

Differentiated SH-SY5Y cells visualized using phase contrast microscopy (A) were treated with $100 \mathrm{nM}$ OA for two hours. Note the differentiated cells with visible neuritic processes. Scale bar $=50 \mu \mathrm{m}$. Total cell lysates were analyzed by immunoblot using anti-tau-pS202 (CP13), anti-tau-pS396 and anti-total tau (Tau46) antibodies (B). Note a strong band migrating around $100-\mathrm{kDa}$ in lysates of OA-treated cells. GAPDH is used as a loading control. 


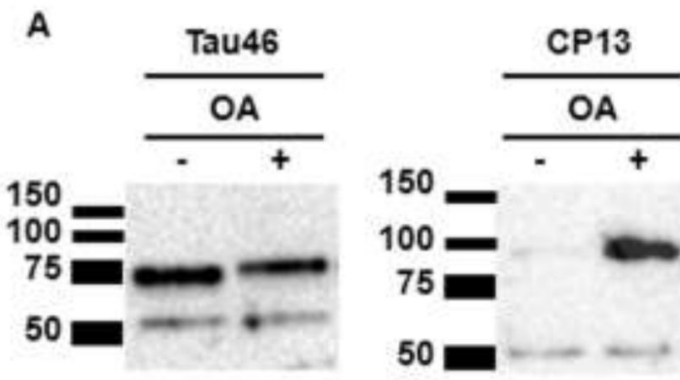

B
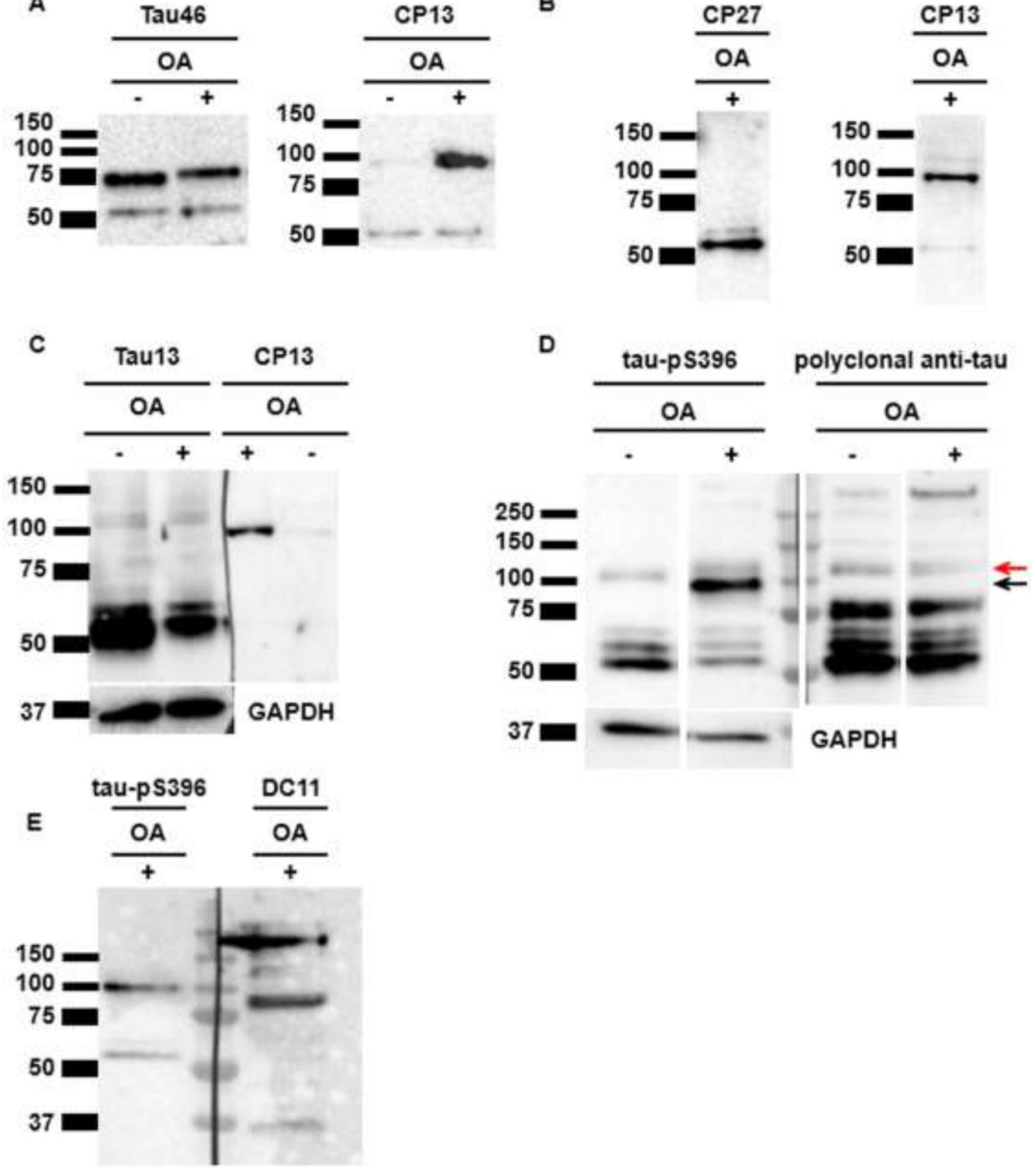

Figure 3. HMW-TIPs are not detected by anti-total tau antibodies.

Where indicated, cells were treated with $100 \mathrm{nM}(\mathbf{A}, \mathbf{D})$ or $150 \mathrm{nM}(\mathbf{B}, \mathbf{C}, \mathbf{E})$ OA for $2-2.5$ hours. Total cell lysates were analyzed by immunoblotting using anti-total tau antibodies Tau46 (A), CP27 (B), Tau13 (C) and rabbit polyclonal antibody (D), and antibody DC11 against truncated tau (E). To visualize HMW-TIPs, same samples were analyzed by antibody CP13 (A-C) or anti-tau-pS396 (D, E). Note a CP13- and anti-tau-pS396- reactive band migrating around $100-\mathrm{kDa}$ in lysates of OA-treated cells (A-E). Note that all anti-total antibodies detect a band migrating above $50 \mathrm{kDa}$ that represents monomeric tau, but do not detect $100 \mathrm{kDa}$ protein (A-D). Tau46 antibody additionally detects a $70 \mathrm{kDa}$ band that 
presumably represents MAP2 isoform (A). GAPDH served as a loading control (C, D). Control and OA-treated samples in (D) were present on the same membrane. Note that the rabbit polyclonal anti-total antibody (right panel) detects a band migrating above $100 \mathrm{kDa}$ tau (red arrow), which is clearly distinct from the OA-induced anti-tau-pS396-reactive band (left panel, $\mathrm{OA}+$ ) migrating at $100 \mathrm{kDa}$ (black arrow). 

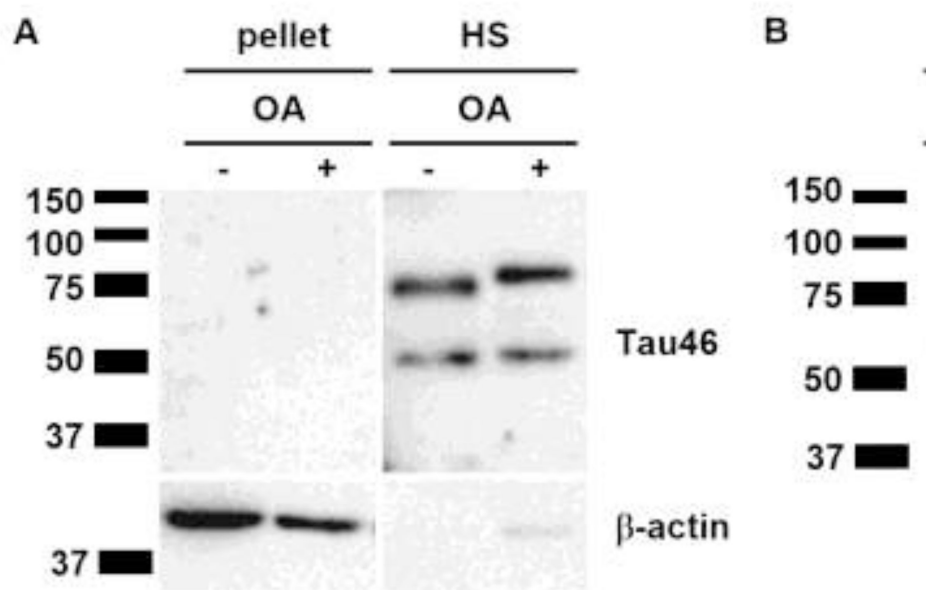

-actin

tau-
pS396

tau-

pS202

Figure 4. HMW-TIP is present in a heat-stable fraction.

SH-SY5Y cells were treated with $100 \mathrm{nM}(\mathrm{OA}+)$ or DMSO (OA-) for 2:15 h. (A) Heatstable (HS) and pellet fractions were analyzed by immunoblot using anti-total tau antibody Tau46 (upper panels) and anti- $\beta$-actin (lower panels). Heat-stable fraction and pellet samples were analyzed on the same nitrocellulose membrane and imaged simultaneously. Note that $50 \mathrm{kDa}$ tau and $70 \mathrm{kDa}$ proteins (70 kDa protein presumably being a MAP2 isoform) detected by Tau46 antibody are enriched in the heat-stable fraction compared to the pellet. In contrast, $\beta$-actin is enriched in the pellet compared to heat-stable fraction. (B) The same samples of heat-stable (HS) fraction as in (A) were analyzed by immunoblot using anti-taupS396 and CP13 (anti-tau-pS202) antibodies. Note the presence of pS396- and CP13immunoreactive $100 \mathrm{kDa}$ bands in the heat stable fraction. 

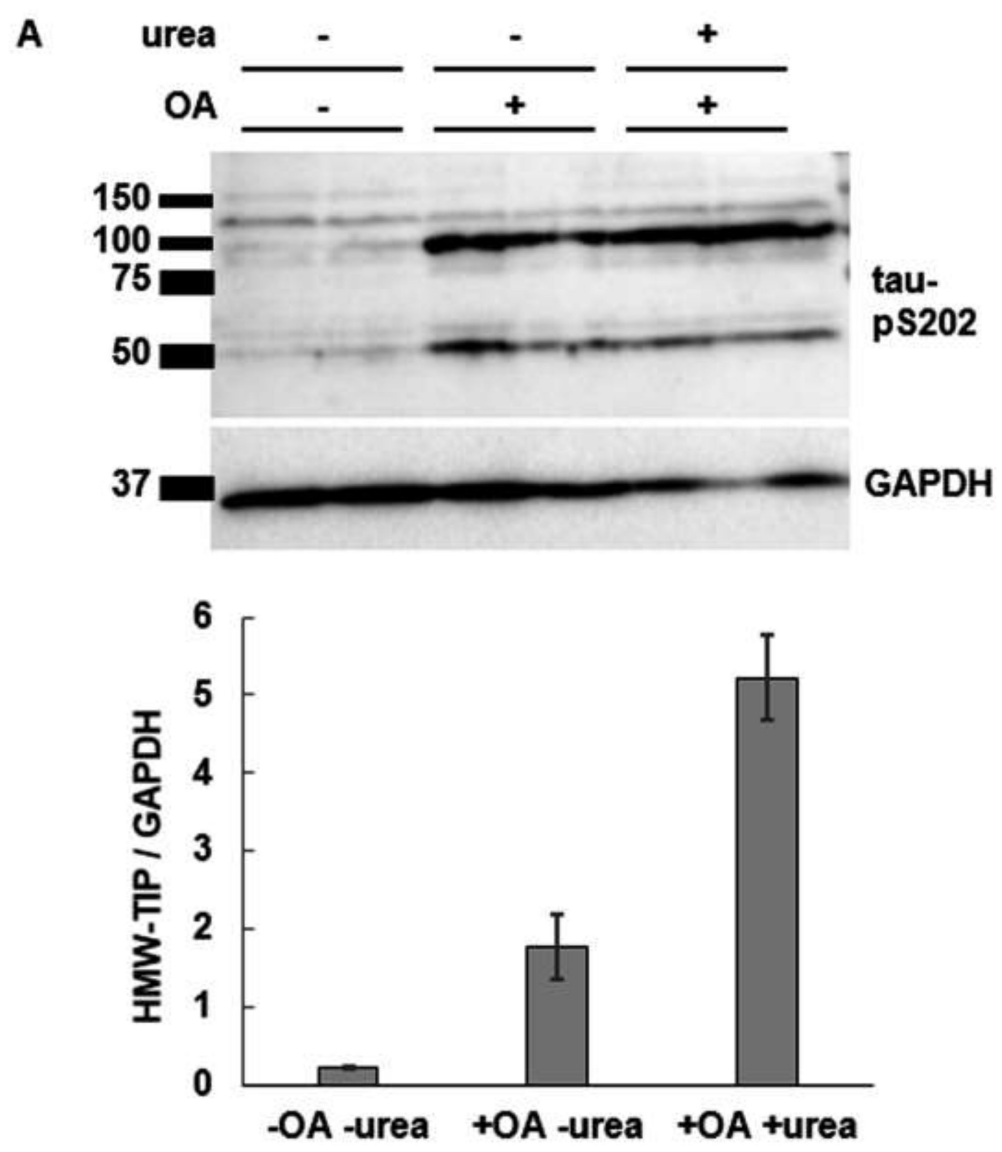

B

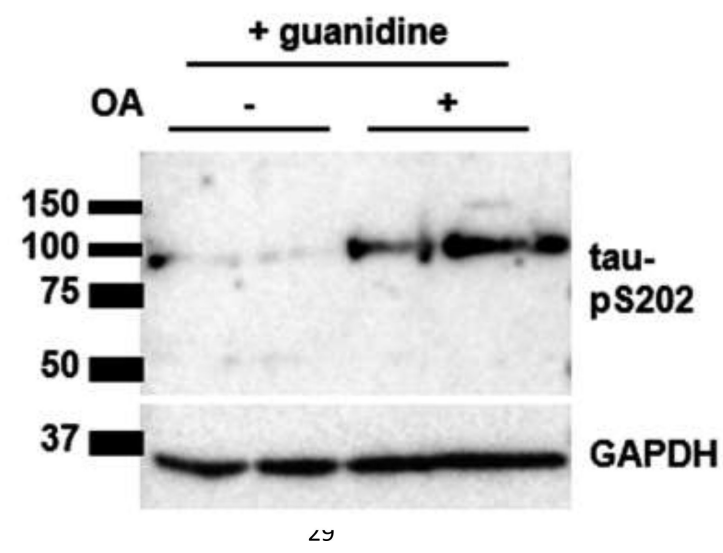

Figure 5. HMW-TIP is stable under denaturing conditions.

Cells were treated with $150 \mathrm{nM}$ (A) or $100 \mathrm{nM}$ (B) OA for $2 \mathrm{~h}$. Cell lysates were prepared in the absence or presence of $8 \mathrm{M}$ urea $(\mathbf{A})$ or with $6 \mathrm{M}$ guanidine-hydrochloride $(\mathbf{B})$.

Immunoblotting was performed using anti-tau-pS202 antibody (CP13). GAPDH was used as a loading control. Note that the $100 \mathrm{kDa}$ band is present in samples from OA-treated cells under all tested conditions. The graph shows signal intensity of HMW-TIP relative to GAPDH levels of the samples shown in A. Average values and standard deviation of replicate samples are shown. 


\section{$+O A$}

$-\mathrm{AP}$

$+\mathrm{AP}$

\section{0}

100
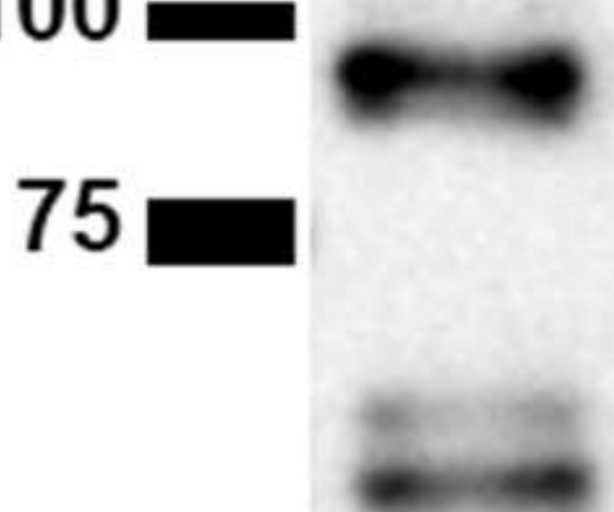

\section{0}

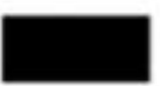

Figure 6. HMW-TIPs stability upon protein dephosphorylation.

Cells were incubated with $100 \mathrm{nM}$ OA for $2 \mathrm{~h}$. Heat-stable fraction was treated with alkaline phosphatase (AP) where indicated and analyzed by immunoblot using anti-tau-pS396 antibody. Note the persistent antibody detection of protein migrating around $100 \mathrm{kDa}$ and changed electrophoretic mobility of proteins treated with alkaline phosphatase. 